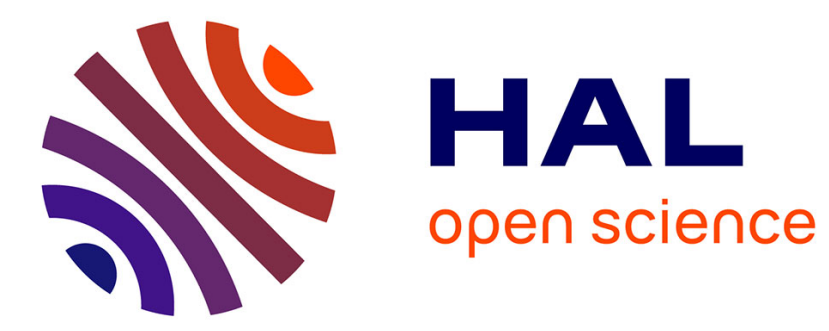

\title{
Towards a Capabilities Approach to Smart City Management
}

\author{
Anushri Gupta, Panos Panagiotopoulos, Frances Bowen
}

\section{To cite this version:}

Anushri Gupta, Panos Panagiotopoulos, Frances Bowen. Towards a Capabilities Approach to Smart City Management. 16th International Conference on Electronic Government (EGOV), Sep 2017, St. Petersburg, Russia. pp.25-35, 10.1007/978-3-319-64677-0_3 . hal-01703000

\section{HAL Id: hal-01703000 \\ https://hal.inria.fr/hal-01703000}

Submitted on 7 Feb 2018

HAL is a multi-disciplinary open access archive for the deposit and dissemination of scientific research documents, whether they are published or not. The documents may come from teaching and research institutions in France or abroad, or from public or private research centers.
L'archive ouverte pluridisciplinaire HAL, est destinée au dépôt et à la diffusion de documents scientifiques de niveau recherche, publiés ou non, émanant des établissements d'enseignement et de recherche français ou étrangers, des laboratoires publics ou privés.

\section{(c)(1)}

Distributed under a Creative Commons Attribution| 4.0 International License 


\title{
Towards a Capabilities Approach to Smart City Management
}

\author{
Anushri Gupta ${ }^{1}$, Panos Panagiotopoulos ${ }^{2}$ and Frances Bowen ${ }^{3}$ \\ School of Business and Management, Queen Mary University of London, London, UK \\ ${ }^{1}$ anushri.gupta@qmul.ac.uk \\ ${ }^{2} \mathrm{p}$.panagiotopoulos eqmul.ac.uk \\ ${ }^{3} \mathrm{f}$. bowen @qmul . ac . uk
}

\begin{abstract}
Smart cites are rapidly gaining momentum but our understanding of their underlying management framework has to a large extent been unexplored. Under the different initiatives within the label of smart cities, there is no systematic understanding of how city decision makers manage the configuration of resources and processes within the dynamic urban environment. This research in progress paper develops a research agenda on the capabilities of smart city management by synthesising the findings of 72 papers. Further to consolidating the enabling aspects of technology and data as key resources is smart city development, the review leads to the identification of dynamic, operational, cultural and management capabilities. The paper concludes by discussing the value of this approach for future work in the area of smart cities.
\end{abstract}

Keywords: Smart city management, capabilities, systematic review

\section{$1 \quad$ Introduction}

Rapid urbanisation, in the early 21 st century, has resulted in complex challenges in the social, environmental, economic aspects of a city. Smart cities have been an important theme of research within the scholarly community, with the use of the term being evident mainly since 1998. An undeniable and important part of developing smarter cities has been about the role digital infrastructure to deliver smart services [1,2]. Nevertheless, there are many more issue to consider as smart cities lie at the intersection of environment, technology and innovation - altogether creating a complex environment for stakeholders to collaborate and co-create value.

Key themes in the smart city literature include innovation, citizens, infrastructure and standards; with focus on the characteristics [3] ;dimensions [4, 5]; social aspects, participatory (smart) governance [6-8] and smart city viability determinants [9]. At large, there is considerable research focusing on integrated digital infrastructure for smart city solutions and citizen-centric governance. As the implementation of smart city initiatives progresses, we need to conceptualise how complicated stakeholder interactions can be managed and sustained within a dynamic urban environment. With 
few exceptions [10,11], such research on the strategic, governance and management elements of smart cities remains mostly at an early stage.

This paper addresses the question of: "Which capabilities can facilitate the effective management of smart city services?" The aim is to present an emerging research agenda on the capabilities of smart city development. This is achieved with the help of a systematic review of 72 relevant papers that provide evidence on how resources are deployed and configured to develop capabilities for smart city management. First we develop the conceptual foundations and then outline the methodology and findings of the review.

\section{Capabilities and the management of smart cities}

Dynamic capabilities are a theoretical concept that originates from the resource-based view of the firm with wide applications in the management literature e.g. $[12,13]$. In the business world, dynamic capabilities refer to processes by which managers develop and configure organisational competencies within dynamically-evolving markets. In the public sector, dynamic capabilities have been introduced in the context of performance improvement, optimal resource management and knowledge sharing where strategic approaches remain prevalent despite the lack of competition $[14,15]$.

In digital government research, capabilities have been used to capture the complex alignment between new technologies and organizational characteristics of government agencies; such examples include business process management [16], interoperability [17] or big data readiness capabilities [18]. In particular, Klievink and Janssen [19] integrate dynamic capabilities with maturity models to describe the stages involved in the implementation of joined-up government. In the context of these applications, capabilities are conceptualised both as an analytical framework to describe how processes of resource configuration occur and a summary concept to outline the different capabilities involved to enable a technological transition (e.g. joined-up government).

A key point from the above studies is that capabilities allow to modify and align resources and process with varying (internal and external) environments. This provides a useful springboard to conceptualise the different complexities involved in the management of smart city initiatives. Smart city managers need to make decisions related to the use of a large pool of resources (e.g. data, people, technology) within a large number of interrelated processes (e.g. new initiatives, existing workflows, local governance frameworks). For instance, Meijer et al. [8] suggest that cities need to be responsive to the rapidly changing external environment and improve the efficiency and sustainability of such initiatives by developing internal capabilities accordingly. Rezende et al. [20] also clearly outline how 'smartness' refers to contextual conditions like the social, economic and political systems along with technology diffusion. Dameri et al. [10] posit that smart city is not only a technical - economic system but also a social system of complicated stakeholder interactions such as local communities, businesses and public-private organisations. At a theoretical level, studies have looked at public value creation and management issues in the context of smart governance $[11,21]$. 
In brief, a capabilities perspective can make a twofold contribution: (1) help consolidate the stream of academic work related to the management of smart cities and (2) point to the specific capabilities that can enable smart city objectives such as shared value creation and asset management, drawing on previous experiences from the current evidence base. In the next section, we outline this approach via a systematic review.

\section{$3 \quad$ Methodology}

A literature review was conducted to collect and assess current evidence regarding the management of smart cities in a systematic and transparent way [22, 23]. We sought to identify the relevant academic sources and overview the evidence from the perspective of capabilities. Based on previous work, a total of 18 relevant search terms used in the smart city domain were identified [24-26]. The search terms were used to query the Web of Science database and extract the relevant literature using the search parameters shown in table 1. The 967 results retrieved from Web of Science were further scrutinised to obtain 72 relevant papers to conduct a systematic literature review. This was done in several stages of iteration after screening the abstracts of the papers for relevance. Relevance was defined in terms of information related to the management of smart cities, e.g. purely technical papers in the field of GIS (geographical information systems), telematics and informatics, decision support systems or articles in the categories of urban planning and development, architecture, psychology were excluded. Also, a few articles in conference proceedings had to be excluded at this stage due to lack of access.

Table 1. Literature Search Terms (Timespan: 1997-2017; Citation Index: SSCI, CPCI-SSH, ESCI)

\begin{tabular}{lll}
\hline Set & Search Terms & Hits \\
\hline \multirow{2}{*}{1} & ("smart city" OR "digital city" OR "intelligent city" OR "virtual city" OR "information city" OR & 791 \\
& "knowledge city" OR "cyber city" OR "eco city" OR "ubiquitous city") & \\
& ("smart cities" OR "digital cities" OR "intelligent cities" OR "virtual cities" OR "information cities" & 578 \\
& OR "knowledge cities" OR "cyber cities" OR "eco cities" OR "ubiquitous cities") & 1091 \\
3 & \#1 OR \#2 & 967 \\
\hline
\end{tabular}

The literature assessment was based on Inan et al. [27] and Teece et al. [12] where organisational capability is composed of operational and dynamic capabilities, both of which are influenced by contextual factors such as organisational culture and learning. Using this as a foundation, several sub-capabilities are identified with respect to dynamic, operational, learning and cultural capabilities. As capabilities are configuration of people, resource, technology and organisations; the capabilities are assessed by identifying the key enablers hinted at in the literature and the way in which the scholars discuss its deployment for value creation. It is the latter that has an implication towards the organisational process (also referred to as routine) being implemented and assists 
to evaluate the impact of configurations of enablers on smart city performance. The routines listed in section 4 are specific to the capability cluster being discussed.

\section{$4 \quad$ Findings}

The 72 papers studied were mainly published between 2006-2016, with an approximate $60 \%$ coverage together in the years 2015 and 2016. Also, out of the 72 papers, 21 were conference proceedings while the rest were journal articles. The most widely covered proceedings were "19th International Scientific Conference on Economics and Management (2 papers)" and "15th IFIP Electronic Government EGOV 8th Electronic Participation EPART Conference (3 papers)"; The journal articles largely covered were "Social Science Computer Review (9)", "Technological Forecasting and Social Change (5)", "Government Information Quarterly (6)", "Innovation and the Public Sector (4)" and "Electronic Government and Electronic Participation (4)". Using Web of Science 'analyse results' feature, it turned out that the major contribution, came from categories like "Information Science Library Science (40.27\%)", followed by "Management (27.77\%)", "Social Sciences Interdisciplinary (23.61\%)" and "Business (20.83\%)".

\subsection{Dynamic Capabilities}

As stated in [12], dynamic capabilities are highly relevant in context of rapid technologically changing markets; thus a technical perspective on capabilities by focusing on the 'digital infrastructure' theme of smart cities. The key enablers identified are technology (sensors, connectivity, digital platforms, smartphones, applications) and data (data science: storage - processing - visualisation). In alignment with Teece et al. [12], the implied routines identified from the literature are: 1) 'sensing' - surveillance of technological externalities on public services, 2) 'seizing'- referring to the context of privacy enhancing technologies and secure transactions, 3) 'transforming' - towards new techniques for optimisation of public services, designed to obtain feedback and 4) 'reconfiguration'- implying at decision-making tools for sustainable realignment of assets with the technological evolving contexts.

Table 2. Overview of Dynamic Capabilities identified

\begin{tabular}{|c|c|c|c|c|}
\hline Enablers & Routines & Capabilities & Description & $\begin{array}{l}\text { Refer- } \\
\text { ences }\end{array}$ \\
\hline $\begin{array}{r}\text { Technological/ } \\
\text { Digital } \\
\text { Infrastructure- }\end{array}$ & $\begin{array}{l}\text { Reconfig- } \\
\text { uration }\end{array}$ & $\begin{array}{l}\text { Technological } \\
\text { Asset } \\
\text { Management }\end{array}$ & $\begin{array}{l}\text { The ability to design tools and techniques for digital infra- } \\
\text { structure maintenance, scaling, data modelling and visuali- } \\
\text { zation; to eventually drive capital }\end{array}$ & {$[28]$} \\
\hline $\begin{array}{l}\text { Enabled by } \\
\text { technology } \\
\text { and data }\end{array}$ & $\begin{array}{r}\text { Sensing } \\
\text { and } \\
\text { Seizing }\end{array}$ & $\begin{array}{l}\text { Digital } \\
\text { Governance } \\
\text { Capability }\end{array}$ & $\begin{array}{l}\text { The ability of policy makers to judge influence of techno- } \\
\text { logical externalities on citizen security and design privacy } \\
\text { considerate policies accordingly. }\end{array}$ & {$[29,30]$} \\
\hline
\end{tabular}


Technological Asset Management.

Considering sensory and unstructured (big) data as an enabler for smart city services, Hashem et al. [28] provide a multi-layered framework for integrated data asset management. The authors highlight how this model aids in reconfiguring the policy implications by making the case of Stockholm. Stockholm incorporated data management of waste collecting vehicles to address traffic and environmental issues which resulted in reconfiguration of policy to a shared waste management vehicle fleet.

\section{Digital Governance Capability}

Belanche-Gracia et al. [29] conducted an empirical study of smartcard payment in Zaragoza Spain. Besides illustrating user generated data as an enabler for optimising public services; the study highlights the need for public authorities to sense privacy and security threats of citizens and act accordingly. In the same context, with examples from Rotterdam, Van Zoonen [30] proposes a $2 \times 2$ privacy framework to aid public authorities to seize security breaches. The privacy framework assesses which technology-data applications are likely to raise privacy concerns.

\section{Digital Enterprise Capability}

By conducting a case study of Trafpoint mobile application, Johannessen et al. [32] illustrate how the deployment of gamification techniques by city authorities, aids in transforming city services. The study depicts that Trafpoint drives implicit participation allowing public authorities to cross reference crowd sourced data.

\subsection{Operational Capabilities}

Operational capabilities are the ability to continuously and efficiently perform daily activities while simultaneously designing techniques to improve performance. While the former implies the 'continuous improvement' routine; the latter hints at 'strategy planning' routine. Capabilities identified here take into consideration the social, economic and political contextual conditions and thus have a key impact on sustainable performance. Here, with respect to the 'innovation' theme in the smart city literature the key enablers identified are mainly 1) data for data-driven innovation, 2) publicprivate partnership for open innovation and 3) citizens for social innovation. In terms of 'leadership management' theme, the key enabler identified is open data.

Table 3. Overview of Operational Capabilities identified

\begin{tabular}{|c|c|c|c|c|}
\hline Enablers & Routine & Capabilities & Description & $\begin{array}{l}\text { Refer- } \\
\text { ences }\end{array}$ \\
\hline $\begin{array}{l}\text { Innovation- } \\
\text { Enabled }\end{array}$ & $\begin{array}{r}\text { Continuous } \\
\text { Improvement }\end{array}$ & $\begin{array}{r}\text { Government } \\
\text { Interoperability }\end{array}$ & $\begin{array}{l}\text { The information sharing ability } \\
\text { amongst municipal levels to be viable. }\end{array}$ & {$[20,32]$} \\
\hline
\end{tabular}




\begin{tabular}{|c|c|c|c|c|}
\hline \multirow{4}{*}{$\begin{array}{r}\text { by data, } \\
\text { public-private } \\
\text { stakehold- } \\
\text { ers and citizens. }\end{array}$} & & \multicolumn{3}{|l|}{ Capability } \\
\hline & & $\begin{array}{r}\text { Social Monitoring } \\
\text { Capability }\end{array}$ & $\begin{array}{l}\text { The ability to foster social innovation } \\
\text { via social media and applications. }\end{array}$ & [33] \\
\hline & & $\begin{array}{l}\text { Performance Management } \\
\text { Capability }\end{array}$ & $\begin{array}{l}\text { Design of tools that foster data driven } \\
\text { decision making besides civic partici- } \\
\text { pation. }\end{array}$ & [34] \\
\hline & & $\begin{array}{r}\text { Cross-sector } \\
\text { Collaboration } \\
\text { Capability }\end{array}$ & $\begin{array}{l}\text { The ability to design techniques that } \\
\text { empower public-private-people part- } \\
\text { nerships to foster entrepreneurial spirit } \\
\text { and strengthen economy. }\end{array}$ & {$[6,21]$} \\
\hline & & $\begin{array}{l}\text { Systems integration and } \\
\text { Co-ordination Capability }\end{array}$ & $\begin{array}{l}\text { The design of systems infrastructure } \\
\text { that allows for capturing holistic view } \\
\text { during decision making }\end{array}$ & [35] \\
\hline $\begin{array}{r}\text { Management - } \\
\text { Enabled by } \\
\text { open data }\end{array}$ & Strategy & $\begin{array}{c}\text { Open Government } \\
\text { Data (OGD) } \\
\text { Capability }\end{array}$ & $\begin{array}{l}\text { Ability to make data about government } \\
\text { operations and decision making to pub- } \\
\text { lic thereby increasing accountability } \\
\text { and transparency in public services. }\end{array}$ & [36] \\
\hline
\end{tabular}

Government Interoperability Capability

By assessing the public services offered by the City Hall in Chicago, Rezende et al. [20] states that e-Gov provides the opportunity for departments within public organisation to redefine the data interoperability systems; consequently fostering data driven innovation. A similar study of eCityGov alliance in the Pacific Northwest of the USA, by Scholl et al. [32], introduces the concept of ICT resource pooling to improve eservices. In this context, ICT are the enablers for governments to continuously improve e-services on the basis of data driven innovation.

\section{Social Monitoring Capability}

Conducting a sentiment analysis on Twitter data, [33] consolidate the manner in which implementation of social media platforms by public bodies enables social innovation fostering civic participation and feedback. This in turn proves beneficial for city authorities to improve welfare services and raise in terms of accountability.

\section{Performance Management Capability}

Abella et al. [34] provide another illustration of data driven innovation in smart cities. In doing so the authors emphasise the need for tools for timely release of information and geo-location of data, to improve city service performance.

\section{Cross-sector Collaboration Capability}

Considering 4P (public-private-people) partnership as a key enabler for smart city services, Nam and Pardo [6] study the case of the Philly 311 non-emergency programme in Philadelphia for effectiveness, efficiency and transparency in service delivery. In this study the author's highlight the importance of both internal and external collaboration (open innovation) to continuously improve services. On similar lines, Chatfield and Reddick [21] study Japan's Kitakyushu smart community project to identify antecedent 
conditions required for smart city implementation. In doing so authors posit that smart city implementations require bottom-up approach; implying collaboration of stakeholders from various sectors in the city to create shared value.

Systems integration and Co-ordination Capability

Taking into account the conflict for policy makers in integrating traditional decision making models with citizen feedback (enabled by open and crowdsourced data); Boukhris et al. [35] propose the multi-criteria decision-making (MCDM) model. This model assists decision makers in strategic planning and provides them with the best alternative(s); as MCDM models allows for ranking and weighing citizen input.

Open Government Data Capability.

Based on the empirical study conducted in Spain, Carrasco and Sobrepere [36] address five dimensions of OGD out of which 'Strategy' dimension has been emphasised as the most important. This dimension assesses the overall vision, governance, institutional and legal framework of open government data initiative.

\subsection{Learning and Cultural Capabilities}

These capabilities are the foundations on which other capabilities are realized. With respect to learning capabilities the key enablers identified are the city stakeholders who regularly hone their skills; while with respect to cultural capabilities the key enablers identified are the city structure and history.

Table 4. Overview of Learning and Cultural Capabilities

\begin{tabular}{|c|c|c|c|c|}
\hline Enablers & Routine & Capabilities & Description & $\begin{array}{c}\text { Refer- } \\
\text { ences }\end{array}$ \\
\hline $\begin{array}{r}\text { City Stake- } \\
\text { holders -Firms, } \\
\text { Government, } \\
\text { University and } \\
\text { Citizens } \\
\end{array}$ & $\begin{array}{l}\text { Skills Training - } \\
\text { (Creativity, Intelli- } \\
\text { gence, Soft Skills, } \\
\text { Hard Skills, Techno- } \\
\text { logical Skills) } \\
\end{array}$ & $\begin{array}{r}\text { Learning } \\
\text { Capability }\end{array}$ & $\begin{array}{l}\text { Considering city as a social system, it is the } \\
\text { ability to develop skills for knowledge based } \\
\text { urban development; where intelligence is the } \\
\text { key to effectively utilise internal and exter- } \\
\text { nal knowledge. }\end{array}$ & {$[37,38]$} \\
\hline $\begin{array}{r}\text { City } \\
\text { Structure } \\
\text { and History }\end{array}$ & $\begin{array}{l}\text { Support Mecha- } \\
\text { nisms/Behaviour that } \\
\text { supports innovation }\end{array}$ & $\begin{array}{r}\text { Cultural } \\
\text { Capability }\end{array}$ & $\begin{array}{l}\text { Ability to build and improve facilities that } \\
\text { encourage tourist attractions, creative talent } \\
\text { and attract inward investment. }\end{array}$ & [39] \\
\hline
\end{tabular}

Learning Capability

The importance of knowledge transfer amongst city actors during the design phase of smart city environments is emphasised by [37]. The authors state that the exchange of domain knowledge is highly tacit in nature; which, at times leads to loss of valuable information. The study suggests that this can be overcome by studying knowledge transfer in human-computer interactions. In a similar context, by assigning knowledge as a central factor to foster productivity of welfare services, Donolo [38] stresses the importance of soft skills as an essential capability in the knowledge society. 


\section{Cultural Capability}

Looking at cities as centres of production and growth - to drive inward investment, Marakatou and Alexndrou [39] stress the importance of factors like city branding, urban environment, presence of prestigious universities.

\section{Conclusion and research agenda}

This research in progress attempts to expand the growing area of smart city management by establishing an initial theoretical connection to the capabilities approach. The review of 72 related papers led to the new types of capabilities that included dynamic, operational, learning and cultural capabilities, which altogether reflect the diversity of approaches in relation to smart city management. Dynamic capabilities assist in decision-making with respect to technological evolution, whereas operational capabilities assist in evaluating changes in terms of socio-economic-political contexts. Cultural and learning capabilities are an antecedent to dynamic and operational capabilities as they relate to the contextual factors of smart cities. The capabilities listed provide a snapshot of the smart city literature in the social sciences.

By consolidating the different aspects of smart city management, several new links also emerge as: (1) dynamic capabilities mainly impact information and policy development of city services, (2) operational capabilities predominantly impact the execution and (3) learning and cultural capabilities influence the procedure of smart city services. Furthermore, the capabilities point to the use of specific resources to achieve smart city outcomes especially, when it comes to new forms of data and information sharing (e.g. social monitoring, interoperability and open data capabilities). This has been better understood by linking the capabilities to illustrative examples from the literature.

Future work can consider both the theoretical and practical levels of smart city capabilities. At the conceptual level, there is scope to link capability development to stage models of smart city evolution and value creation activities. Such an approach seems possible at the stage where both the implementation of smart cities is progressing rapidly and there is a body of related academic work (most relevant papers in the review were published recently). At the practical level, although the integration of the resources within city infrastructure and citizen adoption is quite established, realising capabilities and underlying processes can allow to explore the configuration of hard and soft infrastructure in cities. Thus, cities with more limited resources can develop smarter and resilient services, catering specifically to the city characteristics.

In terms of empirical studies, capabilities can be a useful lens both for case study explorations of smart city management and as a framework to design survey-based instruments. Particularly related to the latter, there is a lot to learn about city managers' perceptions of the enablers of smart city management. There is good scope to identify new capabilities that have yet to be reported within the academic literature but are related to the challenging implementation of new initiatives such as different types of data- open data [36] , crowdsourced data [31] and big data [28]. A practical example of a complex data driven decision making platform is London Datastore. It aims to create a city data market by 'opening' the data collected at the expense of the public, to all. 
However, such platforms face issues like data sharing, interoperability. Thus, a future research agenda which assesses capabilities like data sharing, data interoperability and even data infrastructures; as part of complex smart city infrastructure seems promising.

\section{References}

1. Harrison, C., Donnelly, I.A.: A Theory of Smart Cities. Proc. 55th Annu. Meet. ISSS - 2011, Hull, UK. 55, (2011).

2. Anthopoulos, L.: Defining Smart City Architecture for Sustainability. Electron. Gov. Electron. Particip. 140-147 (2015).

3. Sinkiene, J., Grumadaite, K., Liugailaite-Radzvickiene, L.: Diversity of theoretical approaches to the concept of smart city. 8th Int. Sci. Conf. "bus. Manag. 2014." 933-940 (2014).

4. Jucevipius, R., Patašieno, I., Patašius, M.: Digital dimension of smart city: critical analysis. Procedia - Soc. Behav. Sci. 156, 146-150 (2014).

5. Gil-Garcia, J.R., Zhang, J., Puron-Cid, G.: Conceptualizing smartness in government: An integrative and multi-dimensional view. Gov. Inf. Q. (2016).

6. Nam, T., Pardo, T.A.: The changing face of a city government: A case study of Philly 311. Gov. Inf. Q. 31, S1-S9 (2014).

7. Rodríguez Bolívar, M.P., Meijer, A.J.: Smart Governance: Using a Literature Review and Empirical Analysis to Build a Research Model.

8. Meijer, A.J., Gil-Garcia, J.R., Rodríguez Bolívar, M.P.: Smart City Research: Contextual Conditions, Governance Models, and Public Value Assessment. Soc. Sci. Comput. Rev. 34, 647-656 (2016).

9. Anthopoulos, L., Fitsilis, P.: Evolution Roadmaps for Smart Cities: Determining Viable Paths. 13th Eur. Conf. eGovernment (ECEG 2013). 27-35 (2013).

10. Dameri, R.P., Benevolo, C.: Governing Smart Cities: An Empirical Analysis. Soc. Sci. Comput. Rev. 34, 693-707 (2016).

11. Castelnovo, W., Misuraca, G., Savoldelli, A.: Smart Cities Governance: The Need for a Holistic Approach to Assessing Urban Participatory Policy Making. Soc. Sci. Comput. Rev. 34, 724-739 (2016).

12. Teece, D.J., Pisano, G., Shuen, A., David Teece, M.J.: Dynamic Capabilities and Strategic Management. Source Strateg. Manag. J. Strateg. Manag. J. 187, 509-533 (1997).

13. Eisenhardt, K.M., Martin, J.A.: Dynamic Capabilities: What Are They? Source Strateg. Manag. J. 21, 1105-1121 (2000).

14. Pablo, A.L., Reay, T., Dewald, J.R., Casebeer, A.L.: Identifying, Enabling and Managing Dynamic Capabilities in the Public Sector. J. Manag. Stud. 44, 687-708 (2007).

15. Kim, S., Lee, H.: The Impact of Organizational Context and Information Technology on Employee Knowledge-Sharing Capabilities. Public Adm. Rev. 66, 370-385 (2006).

16. Niehaves, B., Plattfaut, R., Becker, J.: Business process management capabilities in local governments: A multi-method study. Gov. Inf. Q. 30, 217-225 (2013).

17. Pardo, T.A., Burke, G.B.: Improving Government Interoperability: A capability framework for government managers. Cent. Technol. Gov. 1-24 (2008).

18. Klievink, B., Romijn, B.-J., Cunningham, S., de Bruijn, H.: Big data in the public sector: uncertainties and readiness. Inf. Syst. Front. 1-17 (2016).

19. Klievink, B., Janssen, M.: Realizing joined-up government - Dynamic capabilities and stage models for transformation. Gov. Inf. Q. 26, 275-284 (2009).

20. Rezende, D.A., Kohls, J.B.: Public services and electronic government Chicago's digital city. In: International Conference on Social Science and Management - ICSSM. pp. 1-9 (2014). 
21. Chatfield, A.T., Reddick, C.G.: Smart City Implementation Through Shared Vision of Social Innovation for Environmental Sustainability: A Case Study of Kitakyushu, Japan. Soc. Sci. Comput. Rev. 34, 757-773 (2016).

22. Tranfield, D., Denyer, D., Smart, P.: Towards a Methodology for Developing EvidenceInformed Management Knowledge by Means of Systematic Review. Br. J. Manag. 14, 207$222(2003)$.

23. Briner, R.B., Denyer, D.: Systematic Review and Evidence Synthesis as a Practice and Scholarship Tool. In: The Oxford Handbook of Evidence-Based Management. pp. 112-129. Oxford University Press / USA, New York (2012).

24. Schaffers, H., Komninos, N., Pallot, M., Trousse, B., Nilsson, M., Oliveira, A.: Smart cities and the future internet: Towards cooperation frameworks for open innovation. Futur. Internet Assem. LNCS. 6656, 431-446 (2011).

25. Komninos, N.: Intelligent cities: Variable geometries of spatial intelligence. Intell. Build. Int. 3, 172-188 (2011).

26. Anthopoulos, L., Fitsilis, P.: Using Classification and Roadmapping techniques for Smart City viability's realization. Electron. J. e-Government. 11, 326-336 (2013).

27. Gurkan Inan, G., Bititci, U.S.: Understanding organizational capabilities and dynamic capabilities in the context of micro enterprises: a research agenda. Procedia -Social Behav. Sci. 210, 310-319 (2015).

28. Hashem, I.A.T., Chang, V., Anuar, N.B., Adewole, K., Yaqoob, I., Gani, A., Ahmed, E., Chiroma, H.: The role of big data in smart city. Int. J. Inf. Manage. 36, 748-758 (2016).

29. Belanche-Gracia, D., Casaló-Ariño, L. V., Pérez-Rueda, A.: Determinants of multi-service smartcard success for smart cities development: A study based on citizens' privacy and security perceptions. Gov. Inf. Q. 32, 154-163 (2015).

30. Van Zoonen, L.: Privacy concerns in smart cities. Gov. Inf. Q. 33, 472-480 (2016).

31. Johannessen, M.R., Berntzen, L.: Smart cities through implicit participation: Using gamification to generate citizen input for public transport planning. In: Electronic Government and Electronic Participation (2016).

32. Scholl, H.J., Alawadhi, S.: Smart governance as key to multi-jurisdictional smart city initiatives: The case of the eCityGov Alliance. Soc. Sci. Inf. 55, 255-277 (2016).

33. Estévez-Ortiz, F.-J., García-Jiménez, A., Glösekötter, P., Rey, U., Carlos, J.: An Application of People's Sentiment From Social Media to Smart Cities. Prof. LA Inf. 25, 1699-2407 (2016).

34. Abella, A., Ortiz-De-Urbina-Criado, M., De-Pablos-Heredero, C.: Information Reuse In Smart Cities' Ecosystems. Prof. La Inf. 24, 1699-2407 (2015).

35. Boukhris, I., Ayachi, R., Elouedi, Z., Mellouli, S., Amor, N. Ben: Decision Model for Policy Makers in the Context of Citizens Engagement: Application on Participatory Budgeting. Soc. Sci. Comput. Rev. 34, 740-756 (2016).

36. Carrasco, C., Sobrepere, X.: Open Government Data: An Assessment of the Spanish Municipal Situation. Soc. Sci. Comput. Rev. 33, 631-644 (2015).

37. Pourzolfaghar, Z., Helfert, M.: Investigating HCI Challenges for Designing Smart Environments. In: HCI In Business, Government, and Organisations: Information Systems, HCIBGO 2016, PT II (2016).

38. Donolo, M.: The knowledge society and the capability approach in the perspective of sustainable development in Europe. In: Vision 2020: Innovation, Development Sustainability, and Economic Growth. pp. 1-5 (2013).

39. Markatou, M., Alexandrou, E.: Urban System of Innovation: Main Agents and Main Factors of Success. Procedia - Soc. Behav. Sci. 195, 240-250 (2015). 